\title{
ANALYSIS OF HEAT AND MASS TRANSFER ON COOLING TOWER FILL
}

\author{
Abdul Aziz Rohman Hakim ${ }^{1 *}$, Engkos Achmad Kosasih ${ }^{2}$ \\ 1) Center for Multipurpose Reactor National Nuclear Energy Agency of Indonesia \\ 2) Department of Mechanical Engineering Faculty of Engineering University of Indonesia \\ *Corresponding author: hakim@batan.go.id
}

\begin{abstract}
ABSTRAK
ANALISIS PERPINDAHAN PANAS DAN MASSA PADA ISIAN MENARA PENDINGIN. Makalah ini membahas perpindahan panas dan massa dalam isian menara pendingin. Dalam penelitian ini, suhu bola kering di bagian bawah isi, kelembaban relatif di sekeliling, kecepatan aliran udara masuk, suhu bola kering yang keluar, kelembaban relatif udara yang keluar, serta suhu air aliran masuk dan aliran keluar pada menara pendingin diukur. Data yang digunakan dalam perhitungan perpindahan panas dan massa dalam pengisian menara pendingin. Kemudian, dilakukan perhitungan perpindahan panas dan massa berdasarkan pendekatan yang diusulkan. Hasilnya dibandingkan dengan data desain. Metode desain dan analogi menunjukkan hasil yang berbeda. Parameter yang mempengaruhi perpindahan panas di menara pendingin diwakili oleh koefisien perpindahan panas $h_{1}$ dan koefisien perpindahan massa $k_{1}$. Hasil perbedaan antara desain dan metode analogi menunjukkan bahwa ada parameter penting yang berbeda. Sangat diperlukan studi lanjut untuk mengetahui hal tersebut.
\end{abstract}

Kata kunci: analogi, desain, panas, massa, perpindahan

\section{ABSTRACT}

ANALYSIS OF HEAT AND MASS TRANSFER ON COOLING TOWER FILL. This paper discusses the transfer process, limited about heat and mass, in the cooling tower fill.. In this research has been measured some parameters. There is the dry-bulb temperature at the bottom fill, ambient relative humidity, airstream velocity entering fill, dry bulb temperature leaving the fill, the relative humidity of air leaving the fill, inlet and outlet water temperature of the cooling tower. Data is used for practical calculations. Then, heat and mass transfer calculations are calculated based on the proposed approach. The results are compared with the design data. The design and analogy method showed a different result. The parameter which influences the heat transfer at the cooling tower is represented by the coefficient of heat transfer $h_{l}$ and coefficient of mass transfer $k_{l}$. The differences result between the design and analogy method shows that there is an important parameter which different. Deeply study needed for it.

Keywords: analogy, design, heat, mass, transfer

\section{INTRODUCTION}

Mechanical draft cooling towers are widely used in the industry for cooling circulating water $[1,2,3]$. Fisenko had developed a mathematical of the mechanical draft cooling tower. The study focussed only on heat and mass transfer of a droplet water flow, and there no film flows [1]. A mathematical model for a counter flow wet cooling tower had been derived by Nenad, which was based on one-dimensional heat and mass transfer. The balance equations were solved numerically to predict the temperature change of air and water, the humidity as a function of cooling tower high. The flow distribution was predicted using computational fluid dynamics (CFD)[4]. Kloppers derived the equation of heat and mass transfer wet cooling towers. Kloppers found Poppe, Merkel, and 
Effectiveness-NTU methods for cooling tower analysis. Kloppers presented the differences in the heat and mass transfer analysis and solution techniques of the Merkel and Poppe methods [5]. Dreyer developed a mathematical model and simulation program for modelling of the counter for the cooling tower splash pack's flow. The predicted transfer characteristics and pressure drop data obtained with the simulation were compared with experimental data. The model predicts the correct trends for both transfer characteristics and pressure drop across the packing material [6]. Klimanek developed the other models. A set of four ODEs occurred on this model, which is describing mass and energy conservation and kinetic. The model solved with the RungeKutta method [7]. Paisarn had studied the theoretical and experimental of the heat and mass transfer characteristics [8]. The calculation of heat and mass transfer with the analogical method on cooling tower fills presented on this paper.

\section{MATHEMATICAL MODELING}

Several indicators influence the transfer process, both heat transfer and mass transfer. There are including the mass flow rates of water and air, relative humidity and temperature of the air entering cooling tower, the water entering cooling tower's temperature, wind velocity, and atmospheric pressure [1]. The processes of both transfers take place in the dominant infill. The schema of it is shown on Fig. 1.

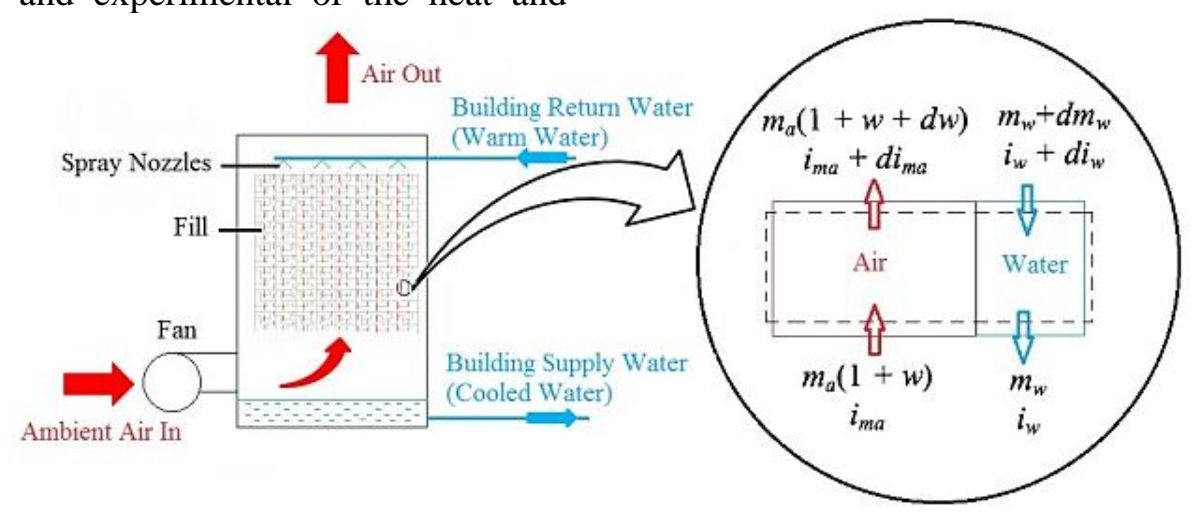

Figure 1. Schema of The Mass and Heat Transfer on Fill [9]

Convection heat transfer from water to air can be calculated by Eq. (1).

$$
\dot{q}_{c}=h_{l} \cdot A \cdot\left(T_{s}-T_{b}\right)
$$

The average water temperature is the average temperature of the water inlet and water outlet temperature from the cooling tower. The average temperature of an inlet and outlet air from the cooling tower is known as average air temperature.

Mass of evaporated water to air can be calculated by Eq. (2).

$$
\dot{m}_{e v}=18 \cdot A \cdot \dot{k_{l}} \cdot C \cdot\left(X_{s}-X_{b}\right)
$$

The mass of water vapour coming out of the cooling tower is the sum of the mass of water vapour contained in the air enters the cooling tower, plus the mass of water vaporized along with the fill. It can be calculated by Eq. (3).

$$
\dot{m}_{v 2}=\dot{m}_{v 1}+\dot{m}_{e v}
$$

The energy balance on a fill takes the form of Eq. (4).

$$
\begin{aligned}
& \dot{m}_{w 2} \cdot C p_{w} \cdot T s_{2}+\dot{m}_{d a} \cdot h_{1}= \\
& \dot{m}_{w 1} \cdot C p_{w} \cdot T s_{1}+\dot{m}_{d a} \cdot h_{2}
\end{aligned}
$$

The heat transferred from water to the air take the form of Eq. (5).

$$
\begin{gathered}
\dot{q}_{d a}=\dot{m}_{d a} \cdot C p_{d a} \cdot\left(T b_{2}-T b_{1}\right)+ \\
\dot{m}_{d a} \cdot \omega_{1} \cdot C p_{V} \cdot\left(T b_{2}-T b_{1}\right)
\end{gathered}
$$

The water entering the cooling tower will be evaporated partially and become cooled water. It takes the form of Eq. (6).

$$
\dot{m}_{w 2}=\dot{m}_{w 1}+\dot{m}_{d a}\left(w_{2}-w_{1}\right)
$$

THE SOLUTION OF
EQUATION 
Eq. (1) to Eq. (6) is a set of six equations describes heat and mass transfer in the fill of cooling tower. The six equation is used to find six unknowns variables. They are $\mathrm{Q}, \mathrm{Mev}$, Tbo, Tso, Wo, and Mwo. The set of six equations must be simultaneous with one another. However, the boundary values found problems in several conditions. There is a boundary value that is known at one point, and something is missing. The input air temperature $\left(\mathrm{Tb}_{1}\right)$ and humidity ratio $\left(\mathrm{w}_{1}\right)$ are known as the boundary conditions at the bottom of the fill $(\mathrm{z}=0)$. water temperature $\left(\mathrm{Ts}_{2}\right)$ and water mass $\left(\mathrm{Mw}_{2}\right)$ at the time of input are also known as the boundary conditions at the top $(\mathrm{z}=\mathrm{H})$. Therefore, the boundary conditions that are missing at the bottom must be found so that the boundary conditions at the top are met, and the equation can be resolved.

Heat transfer coefficient (hl) and mass transfer coefficient $(\mathrm{kl})$ have to be determined first before a set of six equations solved. Nusselt and Sherwood numbers determine them. Both dimensionless numbers calculated from measured parameters. The value of the heat transfer coefficient $h_{1}$ is $17.6319 \mathrm{~W} / \mathrm{m}^{2} \mathrm{~K}$, and the value of the mass transfer coefficient is $0.0155 \mathrm{~kg} / \mathrm{m}^{2} \mathrm{~s}$.

\section{RESULTS AND DISCUSSION}

Below is a sample analysis. The results show the filling conditions in the wet cooling tower. This filling simulation was carried out for height $\mathrm{H}=1.5 \mathrm{~m}$ and Diameter for internal content $\mathrm{R}=0.0225 \mathrm{~m}$. The air velocity is 2.83 $\mathrm{m} / \mathrm{s}$. The water mass flow rates are $1.22 \mathrm{E}-2$ $\mathrm{kg} / \mathrm{s}$. The air inlet temperature is $30.96^{\circ} \mathrm{C}$. The water inlet temperature is $39.2^{\circ} \mathrm{C}$. The wet-bulb temperature is $28^{\circ} \mathrm{C}$. The results of the analysis are presented in Fig. 2 to Fig. 5. The nodes indicate the values of step size.

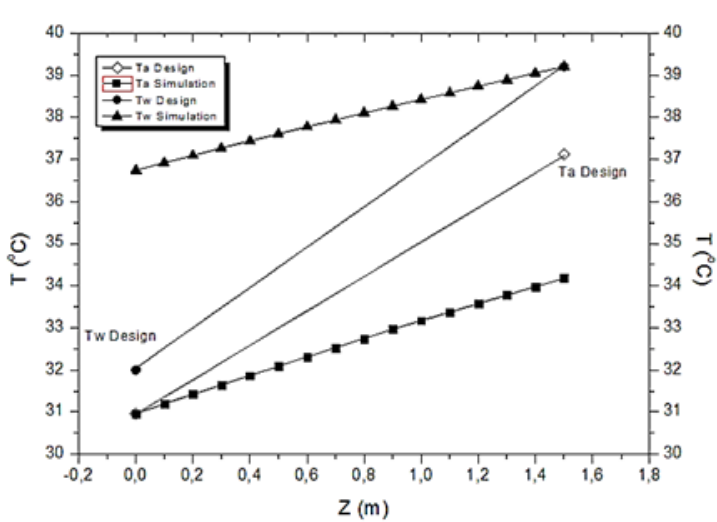

Figure 2. Temperature of air and water in the fill

The air and water temperature profiles are shown in Fig. 2. Air flowing upward increases in temperature from the bottom to the top of the fill. The output air temperature of the fill is heater than the input air. Water temperature decreases. They are starting from the top of the field to the bottom of the field. The process of cooling water is more dominated by evaporative heat transfer than convective heat transfer. At the design, the water is cooled from $39.2^{\circ} \mathrm{C}$ to $32^{\circ} \mathrm{C}$. The temperature range of the design is $7.2^{\circ} \mathrm{C}$. At the simulation, the water temperature is decreased by $2.46^{\circ} \mathrm{C}$. This value is far small than the design value. At a similar ambient condition, at the design calculation, the water temperature decreased larger than simulation. It means that the value of heat transfer at design is larger than the simulation. The parameter which influences the heat transfer at the cooling tower is represented by the coefficient of heat transfer $\mathrm{h}_{1}$ and coefficient of mass transfer $\mathrm{k}_{1}$. The differences result between simulation and design shows that there is an important parameter which different.

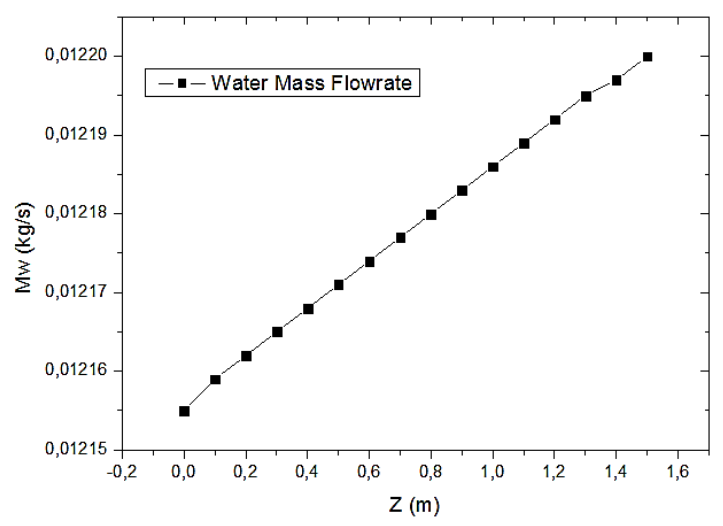

Figure 3. The flowrate of water mass in the fill 
Figure 3 Figure 3 shows the distribution of water's mass flow rate. The mass flow rate of water decreases starts from the top of the fill linearly until the bottom of the fill. When water contact with the air through the fill, the water temperature decrease. It is because of heat extraction from water to the air and evaporation of some water. The evaporated water brings the heat to dan its mass to the air. It makes the flowrate of water decreases along with the fill.

The humidity and saturation humidity distribution along with the fill is shown in Fig. 4. The curve of the humidity ratio does not cross the curve of the saturated humidity ratio. It can be said that supersaturated conditions do not occur based on these information. The air enters the bottom part of the fill with humidity ratio $w_{0}$. Along with the fill, the humidity ratio increases. It can be occurred because of the evaporation of water when water contact with the air. When the humidity ratio cross with a saturation humidity ratio, it means that the air becomes supersaturated.

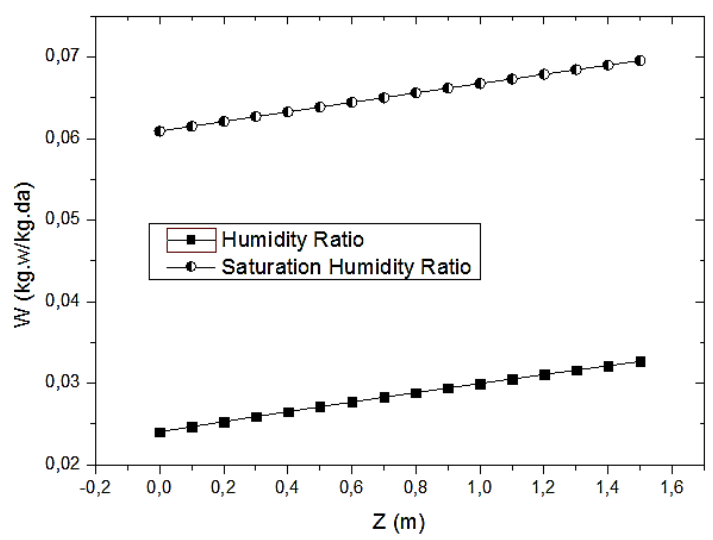

Figure 4 . The ratio of humidity and saturation humidity in the fill

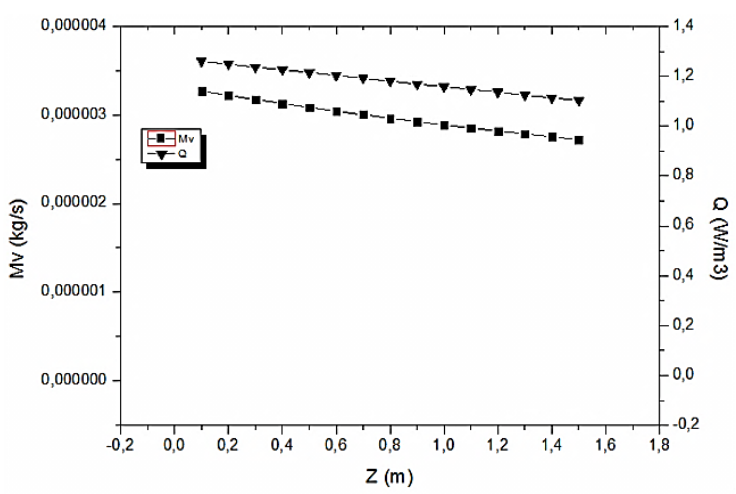

Figure 5. The source of heat and mass in the fill
The heat and mass source distribution along with the fill, is shown in Fig. 5. Both curves have a similar trend. The entering air has a high potential to accept extracted heat through convective heat transfer from the water and evaporated water. It can occur at the bottom of the fill. Entering air contains low mass water represented by humidity ratio. The low value of humidity ratio at the bottom part means the ability to accept evaporated water more significantly than the air at the top part. This condition caused the evaporated water to decrease along with the fill. The heat extracted from water to air also decreased along with the fill because the heat transferred dominant by evaporation.

\section{CONCLUSIONS}

This paper also showed the analogy method of heat and mass transfer process in the fill. The design and analogy method showed a different result. The parameter which influences the heat transfer at the cooling tower is represented by the coefficient of heat transfer $h_{1}$ and coefficient of mass transfer $k_{l}$. The differences result between the design and analogy method shows that there is an important parameter which different. Deeply study needed for it.

\section{LIST OF SYMBOLS}

$\dot{q}_{c}:$ : Convection heat transfer $\left(\mathrm{Wat} / \mathrm{m}^{2}\right)$

$h_{l} \quad$ : Coefficient of convection heat transfer $\left(\mathrm{W} / \mathrm{m}^{2} .{ }^{\circ} \mathrm{C}\right)$

$A \quad$ : Heat and mass transfer area $\left(\mathrm{m}^{2}\right)$

$T_{S} \quad:$ Average water temperature $\left({ }^{\circ} \mathrm{C}\right)$

$T_{b} \quad: \quad$ Average bulk air temperature $\left({ }^{\circ} \mathrm{C}\right)$

$\dot{q}_{d a}:$ : Heat rate accepted by air $\left(\mathrm{Watt} / \mathrm{m}^{2}\right)$

$C p_{d a}:$ Specific heat of the air $\left(\mathrm{J} / \mathrm{kg} .{ }^{\circ} \mathrm{C}\right)$

$\mathrm{Tb}_{2}$ : Air leaving temperature from cooling tower fill $\left({ }^{\circ} \mathrm{C}\right)$

$T b_{1} \quad$ : Air entering temperature to cooling tower fill $\left({ }^{\circ} \mathrm{C}\right)$

$w_{1} \quad$ : Humidity ratio of air entering to cooling tower fill (kg.v/kg.a)

$\dot{m}_{e v}:$ Evaporated mass water rate $(\mathrm{kg} / \mathrm{s})$

$k_{l} \quad:$ Coefficient of mass transfer $\left(\mathrm{kg} / \mathrm{m}^{2} . \mathrm{s}\right)$

C : The concentration of dry air $(\mathrm{kmol} / \mathrm{kg} \mathrm{K})$

$X_{S} \quad: \quad$ An average of water vapour fraction

$X_{b} \quad$ : An average of water vapour fraction 
in dry air

$\dot{m}_{w 2} \quad$ : Water mass flow rate entering cooling tower $(\mathrm{kg} / \mathrm{s})$

$C p_{w} \quad: \quad$ Specific heat of water $\left(\mathrm{J} / \mathrm{kg} \cdot{ }^{\circ} \mathrm{C}\right)$

$T s_{2} \quad$ : Water temperature entering cooling tower $\left({ }^{\circ} \mathrm{C}\right)$

\section{REFERENCES}

1. S. P. Fisenko, A. A. Brin, and A. I. Petruchik, "Evaporative cooling of water in a mechanical draft cooling tower," International Journal of Heat and Mass Transfer, vol. 47(1), pp. 165-177, 2004

2. S. P. Fisenko and A. A. Brin, "Simulation of a cross-flow cooling tower performance," International Journal of Heat and Mass Transfer, vol. 50(15), pp. 3216-3223, 2007

3. S. P. Fisenko and A. I. Petruchik, "Toward to the control system of the mechanical draft cooling tower of film type," International journal of heat and mass transfer, vol. 48(1), pp. 31-35, 2005

4. N. Milosavljevic and P. Heikkilä, "A comprehensive approach to cooling tower design," Applied Thermal Engineering, vol. 21(9), pp. 899-915, 2001

5. J. C. Kloppers and D.G. Kröger, "A critical investigation into the heat and mass transfer analysis of counterflow wetcooling tower," International journal of heat and mass transfer, vol. 48(3), pp. 765777, 2005.

6. A. A. Dreyer and P. J. Erens, "Modelling of cooling tower splash pack," International journal of heat and mass transfer, vol. 39(1), pp. 109-123, 1996

7. A. Klimanek and R. Białecki, "Solution of heat and mass transfer in counterflow wetcooling tower fill," International Communications in Heat and Mass Transfer, vol. 36(6), pp. 547-553, 2009

8. P. Naphon, "Study on the heat transfer characteristics of an evaporative cooling tower," International communications in heat and mass transfer, vol. 32(8), pp. 1066-1074, 2005

9. M. F. Nasrabadi, Donal, Costelloe, Ben, 10th IIR Gustav Lorentzen Conference, June 25-27 2012, Delft, The Netherlands, 2012 
Jurnal Forum Nuklir (JFN), Volume 14, Nomor 1, Mei 2020 